\title{
Risperidone use in preschool children with aggressive and destructive behavioral symptoms
}

\author{
Caner MUTLU, ${ }^{1}$ Özden ŞÜKRAN ÜNERI, ${ }^{2}$ Canan TANIDIR, ${ }^{1}$ Hatice GÜNEŞ, ${ }^{1}$ Mazlum \\ ÇÖPÜR, ${ }^{3}$ Ali Güven KILIÇOĞLU, ${ }^{1}$ Hilal ADALETLI, ${ }^{1}$ Hamiyet IPEK, ${ }^{1}$ Ayten ERDOĞAN ${ }^{4}$
}

\begin{abstract}
Objective: We aimed to investigate the prevalence and mode of risperidone use in preschool aged children admitted with a chief complaint of aggressive and destructive behavioral symptoms. Methods: In this retrospective chart review study, medical records of the patients were reviewed for age, gender, primary and comorbid diagnoses, dosage and duration of risperidone treatment. Dosage and duration of risperidone treatment were compared among primary diagnoses. Results: In 2790 children prevalence of risperidone use was $18.5 \%(n=516)$. Mean age was $4.86 \pm 1.12$ years. Of these patients, \%74.4 had primary diagnosis of a disruptive behavior disorder (DBD). Mean starting dosage of risperidone was $0.35 \mathrm{mg} /$ day and mean maintenance dosage was $0.52 \mathrm{mg} / \mathrm{day}$. The mean length of treatment was 4.9 months. Starting and maintenance doses were significantly higher and treatment duration was longer in patients with mental retardation (MR) than in those with DBDs. Conclusion: In preschoolers, risperidone is frequently used to control aggressive and destructive behavioral symptoms which may improve with higher doses and longer treatment in those with MR. The development of evidence-based treatment modalities for children with aggressive and destructive behaviors necessitates controlled studies and confirmation of their pertinence to clinical practice. (Anatolian Journal of Psychiatry 2015; 16(3):212-219)
\end{abstract}

Key words: risperidone, preschool, children, prevalence

\section{Agresif ve yıkıcı davranışsal belirtileri olan okul öncesi çocuklarda risperidon kullanımı}

ÖZET

Amaç: Temel olarak agresif ve yıkıcı davranışsal belirtiler ile başvuran okul öncesi çağdaki çocuklarda risperidon kullanım yaygınlığı ve özelliklerini araştırmayı amaçladık. Yöntem: Bu geriye dönük dosya tarama çalışmasında, hastaların tıbbi kayıtları yaş, cinsiyet, birincil ve eş tanılar, risperidon dozu ve tedavi süresi açısından gözden geçirildi. Risperidon dozu ve tedavi süresi birincil tanılar arasında karşılaştırıldı. Bulgular: Risperidonun 2790 çocuk-

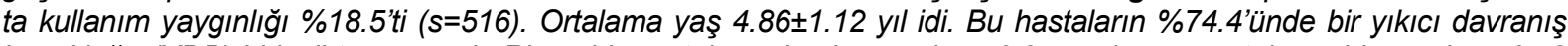
bozukluğu (YDB) birincil tanısı vardı. Risperidon ortalama başlangıç dozu $0.35 \mathrm{mg} / \mathrm{gün}$ ve ortalama idame dozu 0.52 mg/gün idi. Tedavinin ortalama süresi 4.9 ay idi. Zeka geriliği (ZG) olan hastalarda, YDB olan hastalara göre, başlangıç ve sürdürme dozları anlamlı olarak daha yüksek ve tedavi süresi anlamlı olarak daha uzundu. Tartışma: Okul öncesi çocuklarda, risperidon MR olan hastalarda daha yüksek dozlarla ve daha uzun süreli tedavi ile azaltılabilen agresif ve yıkıcı davranışsal belirtilerini kontrol etmek için sıklıkla kullanılır Agresif ve yıkıcı davranışları olan çocuklar için

\footnotetext{
${ }^{1}$ M.D., ${ }^{3}$ Assoc.Prof.Dr., Department of Child and Adolescent Psychiatry, Bakirkoy Prof Dr Mazhar Osman Research and Training Hospital for Psychiatry, Neurology and Neurosurgery, Istanbul, Turkey

${ }^{2}$ Assoc.Prof.Dr., Department of Child and Adolescent Psychiatry, Ankara Pediatric and Pediatric Hematology Oncology Training and Research Hospital, Ankara, Turkey

${ }^{3}$ Prof.Dr., Department of Child and Adolescent Psychiatry, Faculty of Medicine, Duzce University, Duzce, Turkey

Correspondence address / Yazışma Adresi:

Dr. Caner MUTLU, Bakırköy Ruh ve Sinir Hastalıkları Hastanesi, Çocuk Psikiyatrisi Kliniği, Bakırköy/lstanbul, Turkey

E-mail: canerrmutluu@yahoo.com

Received: May $21^{\text {st }} 2014$, Accepted: July $21^{\text {st }} 2014$, doi: $10.5455 / a p d .167083$
}

Anatolian Journal of Psychiatry 2015; 16:212-219 
kanıta dayalı tedavi yöntemlerinin geliştirilmesi kontrollü çalışmalara ve onların klinik pratiğe uygunluğunun onayını gerektirir. (Anadolu Psikiyatri Derg 2015; 16(3):212-219)

Anahtar sözcükler: Risperidon, okul öncesi, çocuk, yaygınlık

\section{INTRODUCTION}

Aggressive and destructive behavioral symptoms were frequently encountered in children with mental retardation (MR), pervasive developmental disorders (PDDs), oppositional defiant disorder (ODD), conduct disorder (CD) and bipolar disorders (BPDs). ${ }^{1}$ Children with aggressive and destructive behavior problems are at significant risk for behavioral, social, familial, and academic difficulties relative to their normal counterparts. ${ }^{2,3}$

It is reported that externalizing behavioral morbidity is $6.9 \%$ for two years old children and $12.9 \%$ for five years old children. ${ }^{4}$ In preschool children, aggressive and destructive behavior symptoms are often serious. ${ }^{5}$ Despite this, only a small proportion of preschoolers with psychiatric disorders is referred for mental health treatment. ${ }^{6}$ Treatments of these children include multidisciplinary interventions due to the frequent cooccurrence of a number of biological, functional and psychosocial risk factors in the development of disruptive behavior problems. ${ }^{2,3}$ Psychosocial therapies like behavioral therapy, psychotherapy and parental counseling and augmentation with pharmacotherapy are the most commonly used treatment modalities. ${ }^{7,8}$ Psychopharmacological treatment of very young patients is a major topic of current research. However, several specific questions are largely unanswered, as current knowledge stems from an extrapolation of information from older children, adolescents, or adults. ${ }^{9,10}$

Typical and atypical antipsychotic medications are used for the treatment of aggressive and destructive behavioral symptoms in children and adolescents. Atypical antipsychotic medications proved to be relatively free of the extrapyramidal symptoms (EPSs) that had limited the use of conventional agents. Available evidence indicates that the use of atypical antipsychotics in children and youth with mental health disorders has increased dramatically. ${ }^{11}$ Risperidone is an atypical antipsychotic that is found to be effective and safe in the short and long-term double-blind, randomized and controlled trials in children and shown to have a good side-effect profile, especially in low doses. ${ }^{12}$

Atypical antipsychotics have Food and Drug
Administration (FDA) indications for schizophrenia, behavioral symptoms in autism, Tourette's disorder, and mixed or manic bipolar episodes in children and adolescents. ${ }^{13,14}$ So, most pediatric use of atypical antipsychotics is off label, that is, prescribed for non-approved psychiatric conditions such as attention deficit hyperactivity disorder (ADHD), ODD and CD that have been unresponsive to psychotherapeutic attempts at treatment. ${ }^{14,15}$ Risperidone has been approved by FDA for disruptive behavior problems in 5-16 years aged children with autistic disorder, acute manic or mixed episodes in 10-17 years aged children with bipolar I disorder and schizophrenia in 13-17 years aged adolescents. ${ }^{16}$ Similarly, as stated in previous sentence, risperidone is often used 'off-label' in Turkish preschool children for a number of mental disorders. ${ }^{17,18}$

Studies investigating the epidemiology of risperidone have generally been restricted to older children and adolescents and the populations of patients with MR or PDDs. In clinical practice psychopharmacological treatment, especially with antipsychotics, is frequently needed in preschool children with disabling behavioral problems due to the limitation of evidence-based psychotherapeutic interventions. ${ }^{19}$ Trends in prescribing psychotropic agents to preschoolers have been accelerating in recent years. ${ }^{20,21} \mathrm{Sec}-$ ond-generation antipsychotics which are also constantly rising constitute an important part of psychotropic prescriptions in preschoolers. ${ }^{5}$ However, there are a few studies examined the patterns of antipsychotics prescriptions for very young children with psychiatric diagnoses..$^{11,22}$ It is important to know the epidemiology of antipsychotics in very young children as it may lead to new studies on the safety and efficacy of these drugs in these age groups. Therefore, in this retrospective chart review study, we aimed to investigate the prevalence and mode of risperidone use and difference for dosage among diagnoses in preschool children with a chief complaint of aggressive and destructive behavior problems.

\section{METHODS}

\section{Subjects and setting}

All patients whose age was within the preschool age range and who underwent a psychiatric eva- 


\section{Risperidone use in preschool children with aggressive and destructive behavioral ...}

luation in Bakirkoy Mental Health Hospital Child and Adolescent Psychiatry Outpatient Clinic between September 1, 2010 and August 31, 2011 were included in the study. This training and research hospital is a tertiary-care (also primary and secondary care) and one of the regional psychiatric specialty hospital located in Istanbul (population approximately 15 million), Turkey. Child and Adolescent Psychiatry Outpatient Clinic responds to mental health concerns of all people under age of 18, living generally within Marmara Region of Turkey. This clinic has a total annual volume of approximately 70.000 patient visits for pediatric population (ages range, 0-17 years). Also, this public hospital usually serves to people with low socioeconomic status.

\section{Procedure}

Firstly, all patients aged six and under were determined from hospital registration database. Then, the files of these patients recorded in the database were retrieved. Medical records of the study subjects who used risperidone were reviewed for age at initial evaluation, gender, primary diagnoses according to Diagnostic and Statistical Manual of Mental Disorders-Fourth Edition (DSM-IV), ${ }^{23}$ starting and maintenance dosage, and the duration of risperidone treatment. Data for improvement, efficacy and side effects which were not recorded regularly in patients' files were excluded from the study. Data were documented in a standardized chart format. Primary diagnoses were grouped into three groups: MR (mild, moderate, severe), PDDs (autistic disorder, atypical autism, pervasive developmental disorder-not otherwise specified [PDD-NOS]) and DBDs (ADHD, ODD, CD, disrupttive behavior disorder-not otherwise specified [DBD-NOS]). Comorbid diagnoses were also recorded in the study. While patients with PDDs and comorbid DBDs were included in PDDs group, patients with MR and comorbid DBDs were included in MR group. The group for patients with both MR and PDDs was determined according to primary or dominant disease. In the study, 103 patients $(20 \%)$ who were prescribed risperidone did not come to next visit and accepted as those lost to follow-up. Forty two patients $(8.1 \%)$ were prescribed last month and no data was collected on their subsequent treatment. For these patients, only starting dosage and demographic data were analyzed. Patient' risperidone dosage and treatment duration were analyzed based on last visit.

Because of retrospective study, there was no need for the approval of the Ethics Committee.

\section{Statistical analysis}

The data was analyzed using SPSS statistical package version 15.0. Prior to analyses, Kolmogorov-Smirnov test was performed to assess the normal distribution of data. Based on distribution, Mann-Whitney $U$ test were used to compare the groups with primary diagnoses for starting and maintenance dosage and treatment duration. The level of significance was set at $p<0.05$.

\section{RESULTS}

Of 2790 children admitted to outpatient clinic during a 12-month period, 516 patients (18.5\%) were administered risperidone for aggressive and destructive behavioral symptoms. The subjects included 395 boys $(76.6 \%)$ and 121 girls $(23.4 \%)$ with an age range of $2-6$ years $(4.86 \pm 1.12)$ at the time of initial evaluation. Three hundred forty of subjects $(65.9 \%)$ were 5 years age and older.

All subjects had aggressive and destructive behavioral symptoms. Target symptoms for risperidone treatment were aggression towards animate or inanimate objects, irritability, opposetional/defiant behaviors, hyperactivity, anger outbursts, risky behaviors, and self-harming behaviors. Primary diagnoses were MR for $12 \%$ $(n=62)$, PDDs for 9.5\% $(n=49)$ and DBDs for $74.4 \%(n=384)$ of these subjects. The rates of comorbidity were $75.8 \%$ for MR group ( $n=47$ ), $53.1 \%$ for PDDs group $(n=26)$ and $40.4 \%$ for DBDs group $(n=152)$. Most common diagnoses were ADHD for MR group ( $n=21)$, DBD-NOS for PDDs group $(n=13)$ and oppositional defiant disorder for DBDs group $(n=101)$. Twenty one $(4.1 \%)$ of the subjects had no diagnosis recorded in the files. Table 1 shows the demographic and clinical characteristics of the subjects.

The duration of risperidone treatment ranged from 1-36 months and mean length of treatment was $4.9 \pm 5.09$ months. The mean starting dose of risperidone was $0.35 \pm 0.17 \mathrm{mg} / \mathrm{day}$, and mean maintenance dose was $0.52 \pm 0.29 \mathrm{mg} / \mathrm{day}$ (Table 2).

There was no significant difference in starting and maintenance doses and treatment duration between the patients with MR and those with PDDs, and between the patients with PDDs and those with DBDs ( $p>0.05)$.

Starting and maintenance doses were significantly higher and treatment duration was longer in patients with MR than in those with DBDs (both $p$ value $>0.05$ ) (Table $3,4,5)$. Also there was no 
Table 1. Demographic and clinical characteristics of the subjects $(n=516)$

\begin{tabular}{lrr}
\hline Characteristics & $\mathrm{n}$ & $\%$ \\
\hline Gender (male) & 395 & 76.6 \\
Age & & \\
2 years old & 17 & 3.3 \\
years old & 51 & 9.9 \\
4 years old & 108 & 20.9 \\
5 years old & 151 & 29.3 \\
years old & 189 & 36.6 \\
DSM-IV diagnoses & & \\
Mental retardation & 62 & 12.0 \\
Mild & 46 & 8.9 \\
Moderate & 13 & 2.5 \\
Severe & 3 & 0.6 \\
Pervasive developmental dis. & 49 & 9.5 \\
Autistic disorder & 27 & 5.2 \\
Atypical autism & 17 & 3.3 \\
PDD-NOS & 5 & 1.0 \\
Disruptive behavior disorders & 384 & 74.4 \\
ADHD & 252 & 48.8 \\
Oppositional defiant disorder & 77 & 14.9 \\
Conduct disorder & 7 & 1.4 \\
DBD-NOS & 48 & 9.3 \\
No diagnoses & 21 & 4.1 \\
$\quad$ & & \\
\hline
\end{tabular}

DSM-IV: Diagnostic and Statistical Manual of Mental Disorders, Fourth Edition; PDD-NOS: Pervasive developmental disorder not otherwise specified; $A D H D$ : Attention deficit hyperactivity disorder; DBD-NOS: Disruptive behavior disorder not otherwise specified

Table 2. Mode of risperidone treatment

\begin{tabular}{lrrr}
\hline & $N$ & mean $\pm S D$ & range \\
\hline Dosages & & & \\
Starting & 516 & $0.35 \pm 0.17$ & $0.25-2 \mathrm{mg} / \mathrm{d}$ \\
Maintenance & 371 & $0.52 \pm 0.29$ & $0.25-2 \mathrm{mg} / \mathrm{d}$ \\
Duration of treatment & 371 & $4.9 \pm 5.09$ & $1-36$ months
\end{tabular}

significant difference in starting and maintenance doses and treatment duration between boys and girls $(p>0.05)$.

\section{DISCUSSION}

The present study may provide data on the use of risperidone in preschool-age children. This study showed that approximately one-fifth of preschool-age children with aggressive and destructtive behavioral symptoms used risperidone mainly for DBDs and to a lesser but significant extent for MR and PDD in a child and adolescent psychiatry clinic of a mental health hospital during one year period. Also it was found that aggressive and destructive behavioral symptoms in MR were required higher doses and longer treatment of risperidone compared to those in DBDs. The findings of present study suggest that risperidone is frequently used to control aggressive and destructive behavioral symptoms of preschool aged children in our clinic, similar to several studies in older children. ${ }^{24-26}$

The prevalence of risperidone administration is $18.5 \%$ in the present study. A few studies have examined the prescription patterns of psychotropic drugs for children with psychiatric diagnoses. In a study of 743 preschoolers with emotional or behavioral problems, $16 \%(n=120)$ of diagnosed children received psychopharmacological treatment, most commonly monotherapy with a stimulant (27). In higher risk populations, such as medically complex toddlers with ADHD and psychiatrically hospitalized young children, reports describe the higher rates of psychopharmacological treatment $(57-79 \%)$ and more prevalent use of more than one medication. $20,28,29$

Olfson et al. ${ }^{22}$ studied recent trends and patterns in antipsychotic treatment of privately insured children aged 2 through 5 years. They found that

Table 3. Starting dosage differences between diagnostic groups

\begin{tabular}{lrccc}
\hline Groups & $\mathrm{n}$ & Starting dosage \\
mean \pm SD & $\mathrm{z}$ & $\mathrm{p}$ \\
\hline Mental retardation & 62 & $0.40 \pm 0.20$ & -0.773 & 0.440 \\
Pervasive developmental disorders & 49 & $0.39 \pm 0.20$ & & \\
Mental retardation & 62 & $0.40 \pm 0.20$ & -3.051 & 0.002 \\
Disruptive behavior disorders & 384 & $0.34 \pm 0.16$ & & \\
Pervasive developmental disorders & 49 & $0.39 \pm 0.20$ & -1.655 & 0.098 \\
Disruptive behavior disorders & 384 & $0.34 \pm 0.16$ & & \\
\hline
\end{tabular}


Table 4. Maintenance dosage differences between diagnostic groups

\begin{tabular}{lrrrr}
\hline \multirow{2}{*}{ Groups } & \multicolumn{3}{c}{ Maintenance dosage } & \\
& $\mathrm{N}$ & mean \pm SD & $\mathrm{z}$ & $\mathrm{p}$ \\
\hline Mental retardation & 40 & $0.72 \pm 0.43$ & -1.653 & 0.098 \\
Pervasive developmental disorders & 40 & $0.56 \pm 0.26$ & & \\
Mental retardation & 40 & $0.72 \pm 0.43$ & -3.628 & 0.001 \\
Disruptive behavior disorders & 276 & $0.49 \pm 0.26$ & & \\
Pervasive developmental disorders & 40 & $0.56 \pm 0.26$ & -1.896 & 0.058 \\
Disruptive behavior disorders & 276 & $0.49 \pm 0.26$ & & \\
\hline
\end{tabular}

Table 5. Treatment duration differences between diagnostic groups

\begin{tabular}{lrrrr}
\hline & \multicolumn{4}{c}{ Treatment duration (month) } \\
Groups & $\mathrm{N}$ & mean \pm SD & $\mathrm{z}$ & $\mathrm{p}$ \\
& & & & \\
\hline Mental retardation & 40 & $8.02 \pm 7.93$ & -0.514 & \multirow{2}{*}{0.607} \\
Pervasive developmental disorders & 40 & $7.10 \pm 8.32$ & & \\
Mental retardation & 40 & $8.02 \pm 7.93$ & -2.435 & 0.015 \\
Disruptive behavior disorders & 276 & $4.27 \pm 3.61$ & & \\
Pervasive developmental disorders & 40 & $7.10 \pm 8.32$ & -1.870 & 0.062 \\
Disruptive behavior disorders & 276 & $4.27 \pm 3.61$ & & \\
\hline
\end{tabular}

annualized rate of any antipsychotic use per 1000 children increased from 0.78 (95\% confidence interval [Cl] 0.69-0.88) (1999-2001) to 1.59 (95\% Cl 1.50-1.68) (2007) (ARR 1.76, 95\% $\mathrm{Cl} 1.56-2.00)$. They found that risperidone accounted for roughly three quarters of total antipsychotic prescriptions (74\%). ${ }^{22}$ Also Olfson et al. ${ }^{30}$ reported that between 1993-1998 and 20052009 , visits with a prescription of antipsychotic medications per 100 persons increased from 0.24 to 1.83 for children, 0.78 to 3.76 for adolescents, The proportion of total visits that included a prescription of antipsychotics increased during this period from $0.16 \%$ to $1.07 \%$ for youths in that study. Psychiatrists provided a larger proportion of the antipsychotic visits for children $(67.7 \%)$ and adolescents $(71.6 \%)$ than for adults $(50.3 \%){ }^{30}$ The prevalence of psychotropic medication in young children is quite different. In a US-MEDICAID sample of 11700 children and adolescents $9.4 \%$ of children aged 4-5 became new users of second-generation antipsychotics between 2001 and 2005. ${ }^{31}$ In a German general population sample of 17450 children, the prevalence of psychotropic medication for 3-6 year olds was $0.26 \%$; about one third of the medication were antipsychotics. ${ }^{32}$ More specifically, $7 \%$ of 3-6 years old children from primary care and daycare sites were prescribed psychotropic medications. ${ }^{21}$

High rate of risperidone administration found in our study may be due to limited psychotherapeutic interventions in our clinic. There are approximately 400 child and adolescent psychiatrists in Turkey that serves approximately 30 million children and adolescents. Our hospital with 10 child and adolescent psychiatrist and 5 allied professionals serves approximately 5 million children and adolescents. Limited number of professionals and inadequate number of training providers may have led evidence-based psychotherapeutic interventions to be less frequently used in our clinic. Also our clinic serves to families with low socioeconomic levels, low parental motivation to participate psychotherapeutic interventions which may be also another reasons of high rate of psychotropic drug administration. In present study, rate of antipsychotic treatment can be much higher if the use of other antipsychotic drugs is taken into consideration in this population. But other antipsychotics are much less frequently used in young children due to lack of approval. ${ }^{22}$

In present study of the patients administered risperidone, approximately three-quarters of pa- 
tients had primary diagnoses of DBDs, including mainly ADHD (49\%) and ODD (15\%). Similarly in a study included Canadian preschool aged children, most common reasons that an atypical antipsychotic was recommended for a child or adolescent were primary diagnosis of ADHD $(17 \%)$, mood disorder (16\%), CD (14\%) and psychotic disorder (13\%). ${ }^{11}$ In Olfson et al. ${ }^{22}$ study from New York, USA, risperidone was mostly recommended for PDDs or MR $(28.2 \%)$, ADHD (23.7\%), and disruptive behavior disorders (DBDs) (12.9\%). Consistent with present study result in study of Olfson et al., ${ }^{30}$ DBDs were the most common diagnoses in child $0-13$ years) and adolescent antipsychotic visits, accounting for $63.0 \%$ and $33.7 \%$, respectively from 2005 to 2009. Inconsistent findings among studies may be due to different study populations; for example, our study has no patients with psychotic disorder or mood disorder. It can be considered that the antipsychotics can be prescribed more frequently at tertiary hospitals than other settings. Also in our study, use of risperidone in ADHD is higher when its use in MR or PDDs comorbid with ADHD is taken into account. Even though risperidone has been approved and studied well in aggressive and destructive behaviors of children with MR and PDDs, our study has pointed out that these behaviors are also very common in children without MR or PDDs.

There was a great variability in the duration of treatment in present study (1-36 months). The mean duration of risperidone treatment in our study was 4.9 months. Similarly for risperidone, the average duration of use was 6 months in a study included Canadian preschool aged children. ${ }^{33}$ Risperidone doses in our study were within $0.25-2 \mathrm{mg} / \mathrm{day}$ range. The findings of this study are generally consistent with data regarding the tolerated use of risperidone in children and adolescents with BPDs, PDDs and DBDs. ${ }^{26,34-37}$

In this study, patients with MR, not with PDDs, used risperidone significantly in higher dose and for longer time, compared to those with DBDs. According to our knowledge, there is no study comparing doses of risperidone required for treatment of aggressive and destructive symptoms in MR, PDD and DBDs. Risperidone at low doses improves lots of behavioral and social symptoms in children with disruptive behavior disorders, including those with normal IQ. ${ }^{26}$ Smaller starting and slower increasing doses of antipsychotics is recommended especially for younger individuals with MR. ${ }^{16}$ Moreover, risperidone is generally increased in time to control disruptive behaviors due to some level of tolerance to medication with long term usage in patients with DBDs. ${ }^{6}$ Although risperidone treatment is suggested to be maintained for a long time, there are no guidelines for the duration of treatment in children. ${ }^{38}$ In the present study, it can be considered that preschoolers with MR, in whom rate of comorbidity is higher, have had more severe aggressive and destructive symptoms required higher initial dose of risperidone and also higher level of tolerance leading higher maintenance dose and longer duration of treatment compared to those with DBDs.

Despite the findings, the present study has several limitations. Retrospective design, heterogeneity of the behavioral problems and absence of a systematic structured assessment are main limitations. Also the facts of relatively small sample size, findings from only one public tertiary hospital and all subjects being Caucasian impede the generalization of the results to preschool children. In addition, absence of evaluation for improvement, efficacy and side effects related to risperidone are important factors that reduce the power of the present study.

In conclusion, our study has pointed out that risperidone is used in a significant proportion of preschool aged children admitted to outpatient clinics and provides informative data on the use of risperidone in preschool aged children with aggressive and destructive behavioral symptoms which are also very common in those without MR or PDDs. Also, preschool aged children with intellectual disability may need risperidone at higher doses for longer treatment. Randomized controlled trials with large samples are needed to explore the efficacy and safety of the short and long term use of risperidone in preschool children with aggressive and destructtive behavioral symptoms, while balancing ethical considerations and the therapeutic needs of the children. 


\section{REFERENCES}

1. Dekker MC, Koot HM, Van der Ende J, Verhulst FC. Emotional and behavioral problems in children and adolescents with and without intellectual disability. J Child Psychol Psychiatry 2002; 43:1087-1098.

2. Egger HL, Angold A. Common emotional and behavioral disorders in preschool children: presentation, nosology, and epidemiology. J Child Psychol Psychiatry 2006; 47:313-337.

3. Lavigne JV, Cicchetti C, Gibbons RD, Binns HJ, Larsen L, DeVito C. Oppositional defiant disorder with onset in preschool years: longitudinal stability and pathways to other disorders. J Am Acad Child Adolesc Psychiatry 2001; 40:1393-1400.

4. Robinson M, Oddy WH, Li J, Kendall GE, de Klerk $N H$, Silburn SR, et al. Pre- and postnatal influences on preschool mental health: a large-scale cohort study. J Child Psychol Psychiatry 2008; 49(10):1118-1128.

5. Stadler C, Bolten M, Schmeck K. Pharmacotherapeutic intervention in impulsive preschool children: The need for a comprehensive therapeutic approach. Child Adolesc Psychiatry Ment Health 2011; 5(1):11.

6. Coskun M, Zoroglu SS, Ozturk MM. Risperidone treatment in preschool children with disruptive behavior disorders: a chart review study. Bulletin of Clinical Psychopharmacology 2011; 21(1):33-41.

7. Langworthy-Lam KS, Aman MG, Van Bourgondien ME. Prevalence and patterns of use of psychoactive medicines in individuals with autism in the Autism Society of North Carolina. J Child Adolesc Psychopharmacol. 2005; 12:311-321.

8. Matson JL, Bamburg JW, Mayville EA, Pinkston J, Bielecki J, Kuhn D, et al. Psychopharmacology and mental retardation: a 10 year review (19901999). Res Dev Disabil 2000; 21:263-296.

9. Jensen PS, Bhatara VS, Vitiello B, Hoagwood K, Feil M, Burke LB. Psychoactive medication prescribing practices for US children: gaps between research and clinical practice. J Am Acad Child Adolesc Psychiatry 1999; 38:557-565.

10. Masi G, Cosenza A, Mucci M, Brovedani P. Open trial of risperidone in 24 young children with pervasive developmental disorders. J Am Acad Child Adolesc Psychiatry 2001; 40(10):1206-1214.

11. Pringsheim T, Panagiotopoulos C, Davidson J, Ho J, CAMESA Guideline Group. Evidence-based recommendations for monitoring safety of second generation antipsychotics in children and youth. $J$ Can Acad Child Adolesc Psychiatry 2011; 20(3):218-233.

12. Pandina GJ, Aman MG, Findling RL. Risperidone in the management of disruptive behavior disorders. J Child Adolescent Psychopharmacol 2006; 4:379-392.
13. Crystal S, Olfson M, Huang C, Pincus H, Gerhard $T$. Broadened use of atypical antipsychotics: safety, effectiveness, and policy challenges. Health Aff (Millwood) 2009; 28(5):w770-781.

14. Lohr WD, Honaker J. Atypical antipsychotics for the treatment of disruptive behavior. Pediatr Ann 2013; 42(2):72-77.

15. Harrison JN, Cluxton-Keller F, Gross D. Antipsychotic medication prescribing trends in children and adolescents. J Pediatr Health Care 2012; 26(2):139-145.

16. Hässler F, Reis O. Pharmacotherapy of disruptive behavior in mentally retarded subjects: A review of the current literature. Dev Disabil Res Rev 2010; 16(3):265-272.

17. Erdogan A, Atasoy N, Akkurt H, Ozturk D, Karaahmet E, Yalug I, et al. Risperidone and liver function tests in children and adolescents: a shortterm prospective study. Prog Neuropsychopharmacol Biol Psychiatry 2008; 32(3):849-857.

18. Ercan ES, Basay BK, Basay O, Durak S, Ozbaran $B$. Risperidone in the treatment of conduct disorder in preschool children without intellectual disability. Child Adolesc Psychiatry Ment Health 2011; 5(1):10.

19. Gleason MM, Egger HL, Emslie GJ, Greenhill LL, Kowatch RA, Lieberman AF, et al. Psychopharmacological treatment for very young children: contexts and guidelines. J Am Acad Child Adolesc Psychiatry 2007; 46(12):1532-1572.

20. Pathak S, Arszman SP, Danielyan A, Johns ES, Smirnov A, Kowatch RA. Psychotropic utilization and psychiatric presentation of hospitalized very young children. J Child Adolesc Psychopharmacol 2004; 14:433-442.

21. Luby JL, Stalets MM, Belden AC. Psychotropic prescriptions in a sample including both healthy and mood and disruptive disordered preschoolers: relationships to diagnosis, impairment, prescriber type, and assessment methods. J Child Adolesc Psychopharmacol 2007; 17(2):205-215.

22. Olfson M, Crystal S, Huang C, Gerhard T. Trends in antipsychotic drug use by very young, privately insured children. J Am Acad Child Adolesc Psychiatry 2010; 49:13-23.

23. American Psychiatric Association. Diagnostic and Statistical Manual of Mental Disorders, fourth ed. (DSM-IV). Washington, DC: American Psychiatric Press, 1994.

24. Turgay A, Binder C, Snyder R, Fisman S. Longterm safety and efficacy of risperidone for the treatment of disruptive behavior disorders in children with subaverage IQs. Pediatrics 2002; 110(3):e34. 
25. Connor DF, Boone RT, Steingard RJ. Psychopharmacology and aggression: II. A meta-analysis of nonstimulant medication effects on overt aggression-related behaviors in youth with SED. J Emot Behav Disord 2003; 11:157-168.

26. Reyes M, Buitelaar J, Toren P, Augustyns I, Eerdekens M. A randomized, double-blind, placebo-controlled study of risperidone maintenance treatment in children and adolescents with disrupttive behavior disorders. Am J Psychiatry 2006; 163:402-410

27. DeBar LL, Lynch F, Powell J, Gale J. Use of psychotropic agents in preschool children: associated symptoms, diagnoses, and health care services in a health maintenance organization. Arch Pediatr Adolesc Med 2003; 157:150-157.

28. Rappley MD, Mullan PB, Alvarez FJ, Eneli IU, Wang J, Gardiner JC. Diagnosis of attentiondeficit/hyperactivity disorder and use of psychotropic medication in very young children. Arch Pediatr Adolesc Med 1999; 153:1039-1045.

29. Rappley MD, Eneli IU, Mullan PB, Alvarez FJ, Wang J, Luo Z, et al. Patterns of psychotropic medication use in very young children with attention-deficit hyperactivity disorder. J Dev Behav Pediatr. 2002;23:23-30.

30. Olfson M, Blanco C, Liu SM, Wang S, Correll CU. National trends in the office-based treatment of children, adolescents, and adults with antipsychotics. Arch Gen Psychiatry. 2012;69(12):12471256.

31. Pathak $P$, West D, Martin BC, Helm ME, Henderson $C$. Evidence-based use of second-generation antipsychotics in a state Medicaid pediatric popu- lation, 2001-2005. Psychiatr Serv 2010; 61(2):123-129.

32. Kölch M, Märsch C, Fegert JM, Lippert HD. Clinical trials with minors in Germany--effects of the 12th amendment to the German Drug Code on the numbers of applications to Institutional Review Boards (IRB). Gesundheitswesen 2009; 71(3):127-133.

34. Biederman J, Mick E, Hammerness $P$, Harpold T, Aleardi M, Dougherty M, et al. Open-label, 8-week trial of olanzapine and risperidone for the treatment of bipolar disorder in preschool-age children. Biol Psychiatry 2005; 58:589-594.

35. Cesena M, Gonzalez-Heydrich J, Szigethy E, Kohlenberg TM, DeMaso DR. A case series of eight aggressive young children treated with risperidone. J Child Adolesc Psychopharmacol 2002; 12:337-345.

36. Luby J, Mrakotsky C, Stalets MM, Belden A, Heffelfinger $A$, Williams $M$, et al. Risperidone in Preschool Children with Autistic Spectrum Disorders: An Investigation of Safety and Efficacy. J Child Adolescent Psychopharmacol 2006; 16:575-587.

37. Aman MG, De Smedt G, Derivan A, Lyons B, Findling RL, Risperidone Disruptive Behavior Study Group. Double-blind, placebo-controlled study of risperidone for the treatment of disruptive behaviors in children with subaverage intelligence. Am J Psychiatry 2002; 159:1337-1346.

38. Canitano R, Scandurra V. Risperidone in the treatment of behavioral disorders associated with autism in children and adolescents. Neuropsychiatr Dis Treat 2008; 4(4):723-730. 